\title{
Deadly Virus Covid 19- An outbreak turns into epidemic in Financial Market
}

\author{
Rishabh Partap Singh \\ Student, SFC Department \\ Galgotias University \\ Uttar Pradesh
}

\begin{abstract}
With persistent human headways and changes the way of life of the human race has changed, advanced and has ended up subordinate to the mechanical variables as well. In this examination we are going to perform an analysis of how the scourge circumstance resulted in a worldwide financial episode in the financial market. The reason for this term paper is to screen the defencelessness and inconsistency with the flare-up of this infection as the hotspot of this scourge isn't as it were having its origins in China but gradually moving to other nations including India. Amid the initial phase of this scourge the China monetary showcase had been influenced but inevitably the declining drop in pandemic within the advertised scattered into other nations leading to global economic crisis.
\end{abstract}

Keywords: Covid-19, Pandemic, Financial Market, Analysis, Global Economic, Crisis

Introduction

The stock markets have been an important spot for every developed and developing economy in the world and since the beginning of the 21 st century it has taken front seat in the journey for development and being an important element to look out for every business industry on this globe, apart from developed countries the developing countries have also witnessed and got to know the role of this market in there development, apart from playing their part in this endeavour the market has also provided a promising career to millions of people worldwide. The primary activity that takes place in these markets is trading; the trading which is being done is of the shares which are offered by the registered companies. The working structure is such that the registered companies float their trading shares in the market with an offer price to the buyers in the market and the bids are called, it is up to the demand in the market which makes the price of the shares change and based on the fluctuations and other factors involved the buyers and sellers perform their trading and incur profit/loss.

Now the environment and the working is such that the volatility of the stock markets 


\section{E-ISSN: 2582-502X Asiatic Gociety for Gocial Siemce Research, Vol 3 (1)}

is such that there is a continuous change in its graphical performance, since the great depression of 2007 these markets have grown with a remarkable difference. Markets like New York Stock Exchange, NASDAQ, Tokyo Stock Exchange, Hong Kong Stock exchange of the developed countries are the leading giants of this stock market structure who regulate billions of dollars in transactions in their working and the markets from developing countries like India, China, Russia, and Brazil have shown a serious uprising. The growth of these markets has also been there due to the globalisation which has taken place in each country and has worked in an integrated path of merging the respective domestic economy with the global economy making these countries and markets connected via direct/indirect working of environment.

Being a development made in a connected way of working it is also a proven fact that the global events and happenings do affect these markets and their performance together, since the outbreak of the pandemic has taken global attention after affecting over millions of people, this is how the markets have reacted to the situation. $31^{\text {st }}$ Dec 2019 the day for stepping in the last year of a decade and starting the traditions of celebrating the new start for the new year with resolutions and parties all around the globe with the exchange of greetings, clutches of cases of pneumonia in Wuhan, Hubei Province were reported to WHO the situation seemed bit strange but had a chaotic situation that was about to get serious in the times to come that one could have ever imagined.

The problem continued to rise with speed and had attracted global attention. Scientists, Doctors and health experts were completely unaware about what situation they were exactly in, and what were the features or the symptoms of this disease as they hadn't seen this thing in their respective careers. The common conclusions made were that the disease was highly contagious and dangerous for people of low immunity (old age people and children) which was caused due to the outbreak of a virus. The virus was named as Coronavirus which is more of an umbrella term that refers to a group of viruses that cause the diseases like SARS, MERS and COVID-19 the term also happens to be a Latin name which means crown.

The WHO (world Health Organisation) monitored the situation and decided to make an official entry in the battleground against the new enemy for the human race i.e. Coronavirus, on 11 Feb 2020 with 44,653 cases WHO named Coronavirus as COVID 19 an announcement of it being a pandemic was officially made by the authorities. Following the huge outbreak the theories regarding the outbreak of the virus continued to spread. It was 


\section{E-ISSN: 2582-502X

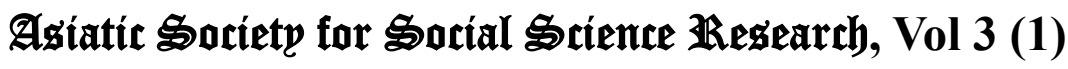

probably believed that the virus may have originated from the certain species of bat as being China, a country with a high popularity of animal markets for the purpose.

However if we follow up the situation the soon after the outbreak the countries around the world started with the extraction procedure of their respective nationals from China and it can be assumed that this is where the virus had got his window to slip to other countries and which did happens making other nations a victim of the virus with $3,567,005$ cases and a death toll of 218,313.Now, since the virus had a severe impact on Wuhan for the starters followed by other Chinese cities went for a lockdown, and since it happened on a global scale many other countries had also faced these lockdowns resulting in ZERO economic activity and a crash of stock markets on worldwide basis.

\section{Literature Review}

According to "John W Goodell" (2020) the brief study mentions the damage caused by the COVID 19 on the global economy but also suggests the potential of epidemics, natural calamities, terrorism etc. as a potential element of inflicting the damage at global and domestic level. It also highlights the role of political standout in these situations and assumes to predict the financial market performance only in the years to come, which has been considered as 'many' in this context. The nuclear warfare threat was also taken into consideration but it's a highly uncurtaining scenario for the human race and hence was left out.

According to "Debjiban Mukharjee" (2006) it was observed that the stock market around the globe has a structural operating body sharing a similarity with each other by having common practice tools like circuit filters as the global markets had mutual challenges to deal with. Moving further it further explains that the on the past performance of the global markets do get affected by the happenings on the domestic level but as these stock markets grew and the respective countries had opened up for globalisation the establishment of a relationship of globalised integrated economy is observed among the stock markets in the past few decades as the performance has observed to work in a relatively coordinated manner.

According to "Sameer Yadav" (2017) it emphasized on the factors/ practices being done in the stock market responsible for bringing a change in the on-going market activity and relative measures which are there in existence against by the responsible authorities. Also it shows the important role of SEBI (securities and exchange board of India) and 
other regulatory authorities to prevent the speculation and other illegal practices to take place and ensure the consecutive working of the stock market and up to what rate of change can we expect in the market over the different volatility factors being mentioned.

According to "Najeb M.H. Masoud" (2013) it presents the role of the stock market and its link in the economic growth, the findings mention that in the era of modern and growing world the stock market has emerged as a contributor to the economy and has played its role in the economic growth for both developed and developed countries in the past and will continue to do the same in future.

According to "Thomas Conlon and Richard McGee" (2020) it investigates the bear market impact on the crypto currencies (like Bitcoin), in further dwelling of research it is shown that though the crypto currency market performs on a different platform as compared to S\&P 500 but it cannot perform/act as a safe haven for investors in the situations such as the on-going pandemic, the myth of appreciation of virtual money having no relation to the on-going situation is busted, moreover it has been observed that adding bitcoin to the portfolio would increase the downside risk for investors rather than only trading in S\&P 500.

According to "Mohshin Ali, Nafis Alam \& Syed Aun R Rizvi" (2020) the study tracks the financial market behaviour towards COVID-19 a global pandemic, the study mentions about the situation from the days back when it was an epidemic and records the journey of becoming a pandemic. Among the securities available to invest in the market in order to incur returns, only gold has survived to be a safe haven for the investment purpose and the other investment options were facing the downgrade due to the on-going situation. In the finding it is also observed that while the European and the US markets were facing the down slope of the market and were experiencing the volatility of the market it is only the Chinese market which had maintained a calm response towards the volatility and the situation and preventing the downfall instead of being the epicentre of the outbreak of the pandemic in the first place.

\section{Objectives of the Study}

1. To study the changes of the Sensex and Nifty index with due to covid 19 cases in India.

2. To overview the possibilities of future outcomes.

3. To find out the impact of Covid 19 on financial market volatility. 


\section{E-ISSN: 2582-502X

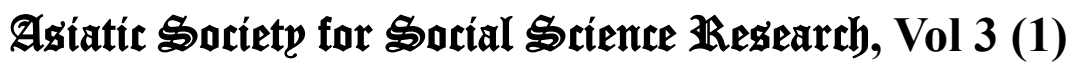

\section{Research Methodology}

The data related to the Stock markets (NSE \& BSE) related information has been taken from various websites and related articles were also taken into consideration for the cause to achieve the first objective. To achieve the second objective the set of data related to daily price and return of Morgan Stanley capital International Index had been taken into account to measure the performance of the stock market. The index of nine countries had been taken into account affected by covid 19 including China, European countries like France, Germany, South Korea along with the United states of America, Italy and Spain. Along with this data the corporate board index and US Treasury bond core index, WTI spot and Gold had been taken in the dataset.

To achieve the first objective the stock market was taken into consideration which included the observatory movement of NSE \& BSE (National Stock Exchange \& Bombay Stock Exchange). The movement is tracked based on the rising COVID-19 cases from 1-2 lakh cases in the past months and the performance of Sensex and Nifty50 is recorded and presented in the following table: -

\begin{tabular}{|l|l|l|}
\hline COVID CASES & SENSEX & NIFTY \\
\hline 1 & $40,913.82$ & $12,035.80$ \\
\hline 100 & $34,103.48$ & $9,955.20$ \\
\hline 1000 & $28,440.32$ & $8,281.10$ \\
\hline 10000 & $30,690.02$ & $8,993.85$ \\
\hline 100000 & $30,028.98$ & $8,823.25$ \\
\hline 200000 & $33,825.53$ & $9,979.10$ \\
\hline
\end{tabular}

Source: As per report by Money control MAY2020

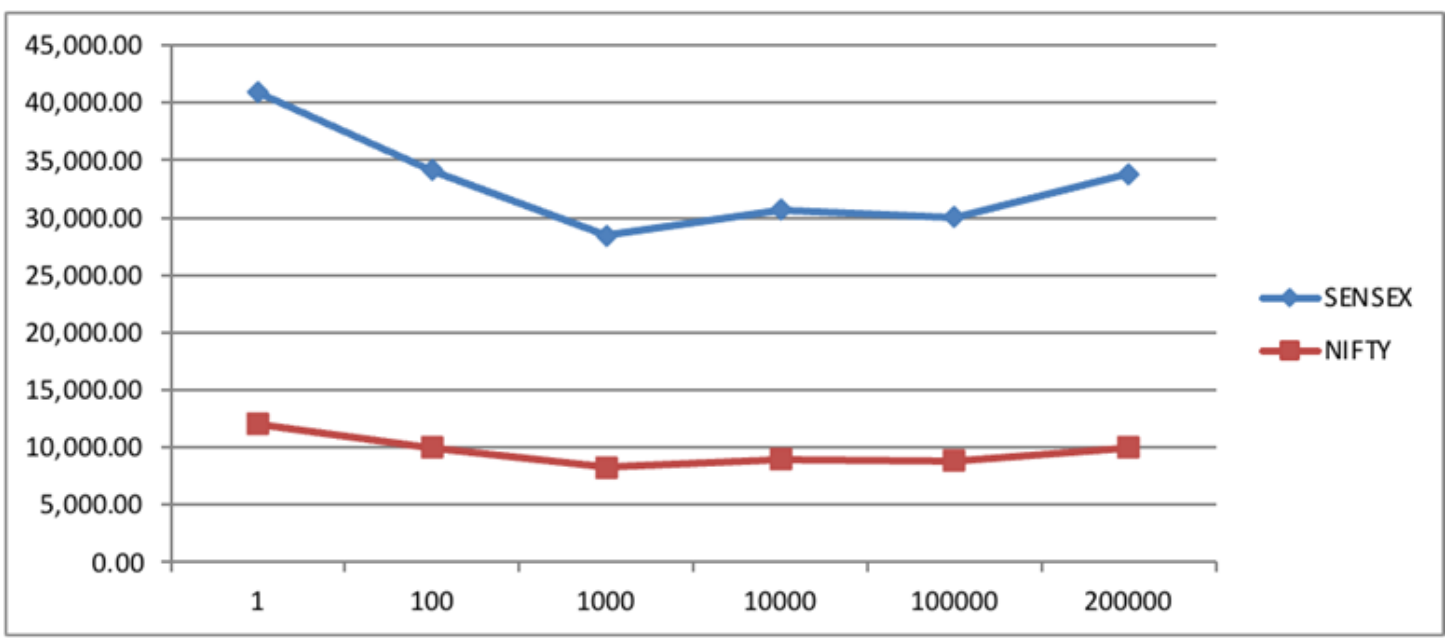




\section{E-ISSN: 2582-502X Asiatic Gociety for Gocial Siemce Research, Vol 3 (1)}

Considering the first case of COVID-19 being encountered in India, we can conclude that before the particular virus discovery in the country the stock market was performing in a good uprising manner. In the above table the COVID-19 cases are taken in a particular manned and the rising level of such cases are also shown above, from which the speed of virus spread can be observed and as per the data shown the highly contagious virus has multiplied itself at remarkable speed specially the rise from 1, 00,000 cases to 2,00,000 cases in a very short interval.

As the first case of Coronavirus is encountered in the country the market was on the mentioned points but a drop was recorded later as the cases reached the number of 100 giving a drop of 6810.34 for Sensex and for Nifty the recorded drop was of 2080.6 points since day 1 but it is also to be brought to attention that the lockdown wasn't announced till then by the government of India. 24/03/2020 the day when the Republic of India was put on a nationwide lockdown by the Hon'ble Prime Minister of India Shri Narendra Damodardas Modi resulted in a sharp drop of economic activities and growth, also the country wasn't performing well with the past economic growth reports and the future crash of economy was also foreseen but in order to strengthen the war against the COVID-19 the government had agreed to bear such huge cost in order to prevent the future consequences.

After the imposition of the nationwide lockdown the cases of the virus continued to rise and the respectively, till now lakhs of cores were recorded in the form of loss from market trading. Since the crisis of 2008 it was the first time that the market had taken a hit of support by the RBI and Govt. for the concerned situation involving the fear of Cases reached a 10,000+ mark again giving a downward push to both Sensex and Nifty totalling to a Cases reached a 10,000+ mark giving a downward push to both Sensex and Nifty sum of 10,223.8 (Sensex) and 3,041.95 (Nifty). investors was also made. In response to such a situation the trading time of the market was altered providing a limited time for business and maintaining the damage control.

Again in the process of witnessing the cases rise to 1, 00,000 it was observed that though the market had taken a dig to its fall there was now a time to witness certain improvements within the trails of trading, it was observed that the market was indeed affected by the pandemic but after falling back to this certain points the market was found to be sustaining and surviving the given situation. Since the 30th Jan 2020 a rise of 2, 00,000 cases has been observed country wide making India on of the top 10 most affected country and the speed of these rise in number from 100, 000 to the current digit (of 200,000) took a 


\section{E-ISSN: 2582-502X Asiatic Gociety for Gocial Siemce Research, Vol 3 (1)}

total of 15 day The possible suspected reason behind such inflow can be suspected of a rising global concerns and a common group of issues, if we talk about the global economic working as a whole China had its utmost and a continue to rise participation in it from almost nothing to almost everything the country has managed to become a major manufacturer in the span of 30 years and by the year 2020 had a major/monopolistic role in manufacturing goods and providing services to almost each country on this planet, now as the outbreak of this virus took place a common negative narrative.

Meanwhile the Indian Stock market had its own challenges and functions to tackle in the pandemic outbreak, the above chart represents the working of the major US stock markets which had also faced the pandemic issue resulting in a steep downfall of the stock market. The steep but it is also to be noted that the country. Maintained a Pandemic situation a panic was also seen to be felt in the market dealings cases. Only $2 \%$ are needed to be taken to the ventilator. Cases reached a 10,000+ mark again giving a downward push to both Sensex and Nifty totalling to a sum of 10,223.8 (Sensex) and 3,041.95 (Nifty). Entire stock markets are now in a lesser sense of regarded fear observed. Also the big boys of the market have come out to be trusted players and have also made their contribution towards the outlasting situation together at a same time the fall recorded had led to the uncalled loss and as the investors had never seen or while facing such a situation the markets like others involved have realised to adapt and operate in such conditions and have also shown a recovery. Specifically, the Nasdaq has shown remarkable performance and showing the growth level of $+11.68 \%$, such performance also signifies a few future possibilities for a country to expect in the long run and that to when the whole nation is the worst affected state from COVID-19 pandemic.

\section{Possibilities of Future Outcome and Functioning}

Since from the track of the market movement a series of changes were observed, having the problem of such a serious pandemic issue the firms of the Indian Stock market were still managing to operate. As a result, there were profits made by the organisations but every organisation did face a back foot of current Due to such a situation not only in the country but also on a global scale, a change of human psychology is observed. Countries like the US, Russia, Brazil, UK, Spain, Italy were the most affected ones and since the outbreak of the virus was observed to come into existence from the wet markets of Wuhan, China.

A revengeful/hate speech has been reported to take a rise to against the Chinese 
administration (being a communist base of working) by various the countries accusing it for the virus outbreak and being a bully to its neighbouring counties over territory issues have opened up dialogues, threatening statements of future consequences, taking the issue to international forums has been taken through diplomatic channels.

This can be potentially a great opportunity for India being the competitor of China to continue to attract the foreign investment and Companies both at the recovery rate of $40 \%$ and out of the total cases only $6.39 \%$ Since the above point mentioned and a stable situation gained by the stock market fall in the above market is a rare fall of the need a hospital support and out of the total it can be assumed that the investors have agreed to be adapted to this situation of the market. Whether it was enabling the flow of investment in such times or carrying on the business from home during lockdown the business houses had and have managed to withstand the situation while bearing a bit of turbulence through right.

At the same time since the reports have mentioned that there are more than 1000 forms of respective countries that have no confidence and intention to continue conducting its business in China have looked up at India as an option to shift their operations which may result as a game changer for the much-needed country's GDP growth. In response to this the state governments of Uttar Pradesh, Andhra Pradesh, and Punjab etc. had already started with the policy formation and adjustments in coordination with the central government in order to attract such companies for their settlement in the respective states.

This change in preference of doing Business will be a rewarding situation for India and would also play a vital role in surging the employment level upwards. Also mentioning the outbreak of such improvements, the stock markets have also shown positive signs thereafter. If the working is adapted to the current style the Stock Market survival probability would be apprehended in positive May and it may make the Indian Stock market the first one to recover on a global level. But it is only possible when the country is able to tackle the pandemic situation and a sense of stability is there within the investors. The role of Government is equally required in this situation.

\section{Impact of Covid 19 on Financial Return and Volatility}

Table 1 highlights the complete statistical report for the return and volatility for the whole period which includes the complete details of mean, standard deviation along with the return. Table 1 show the return . 


\begin{tabular}{|l|l|l|l|l|}
\hline & $\begin{array}{l}\text { Mean } \\
(\%)\end{array}$ & $\begin{array}{l}\text { Standard } \\
\text { Deviation } \\
(\%)\end{array}$ & $\begin{array}{l}\text { Min. } \\
(\%)\end{array}$ & $\begin{array}{l}\text { Max. } \\
(\%)\end{array}$ \\
\hline WRLD & -0.61 & 2.73 & -10.44 & 5.75 \\
\hline EUR & -0.69 & 2.46 & -14.06 & 1.81 \\
\hline USA & -0.59 & 3.34 & -12.92 & 8.71 \\
\hline ASIA & -0.49 & 1.46 & -5.19 & 2.75 \\
\hline ITL & -0.77 & 3.49 & -20.54 & 6.60 \\
\hline SPN & -0.74 & 3.07 & -17.22 & 5.32 \\
\hline CHN & -0.29 & 1.86 & -6.09 & 3.79 \\
\hline GER & -0.77 & 2.67 & -15.09 & 3.69 \\
\hline FRA & -0.74 & 2.78 & -14.90 & 5.12 \\
\hline KOR & -0.66 & 2.97 & -11.00 & 10.05 \\
\hline SWZ & -0.38 & 2.02 & -11.33 & 3.91 \\
\hline UK & -0.85 & 2.52 & -14.21 & 1.57 \\
\hline BC & -0.31 & 6.28 & -31.57 & 15.83 \\
\hline WTI & -1.48 & 7.31 & -38.83 & 21.36 \\
\hline GLD & -0.04 & 1.31 & -4.88 & 2.59 \\
\hline Trsry & 0.12 & 0.72 & -2.10 & 1.82 \\
\hline S\&P & -0.17 & 0.83 & -3.42 & 0.81 \\
\hline
\end{tabular}

Table 1: Volatility

Table 2 shows the return and volatility during the epidemic time on 10 March 2020 Table 2: Return

\begin{tabular}{|l|l|l|l|l|}
\hline & $\begin{array}{l}\text { Mean } \\
(\%)\end{array}$ & $\begin{array}{l}\text { Standard } \\
\text { Deviation } \\
(\%)\end{array}$ & $\begin{array}{l}\text { Min. } \\
(\%)\end{array}$ & $\begin{array}{l}\text { Max. } \\
(\%)\end{array}$ \\
\hline WRLD & -0.28 & 1.66 & -7.44 & 3.27 \\
\hline EUR & -0.41 & 1.49 & -6.92 & 1.64 \\
\hline USA & -0.23 & 2.04 & -7.99 & 4.77 \\
\hline ASIA & -0.23 & 1.07 & -4.17 & 1.90 \\
\hline ITL & -0.53 & 2.09 & -11.01 & 2.41 \\
\hline SPN & -0.47 & 1.70 & -7.88 & 1.76 \\
\hline CHN & -0.08 & 1.47 & -4.44 & 2.81 \\
\hline GER & -0.44 & 1.53 & -7.15 & 1.49 \\
\hline FRA & -0.46 & 1.57 & -7.52 & 1.69 \\
\hline KOR & -0.25 & 2.02 & -5.61 & 3.83 \\
\hline SWZ & -0.20 & 1.29 & -4.58 & 2.08 \\
\hline UK & -0.52 & 1.58 & -7.60 & 1.57 \\
\hline BC & 0.22 & 3.84 & -15.07 & 6.96 \\
\hline WTI & -1.15 & 5.89 & -38.83 & 9.87 \\
\hline GLD & 0.17 & 0.95 & -3.78 & 2.59 \\
\hline Trsry & 0.16 & 0.54 & -2.05 & 1.82 \\
\hline S\&P & 0.08 & 0.36 & -1.74 & 0.81 \\
\hline
\end{tabular}




\section{E-ISSN: 2582-502X \\ Asíatic Society for}

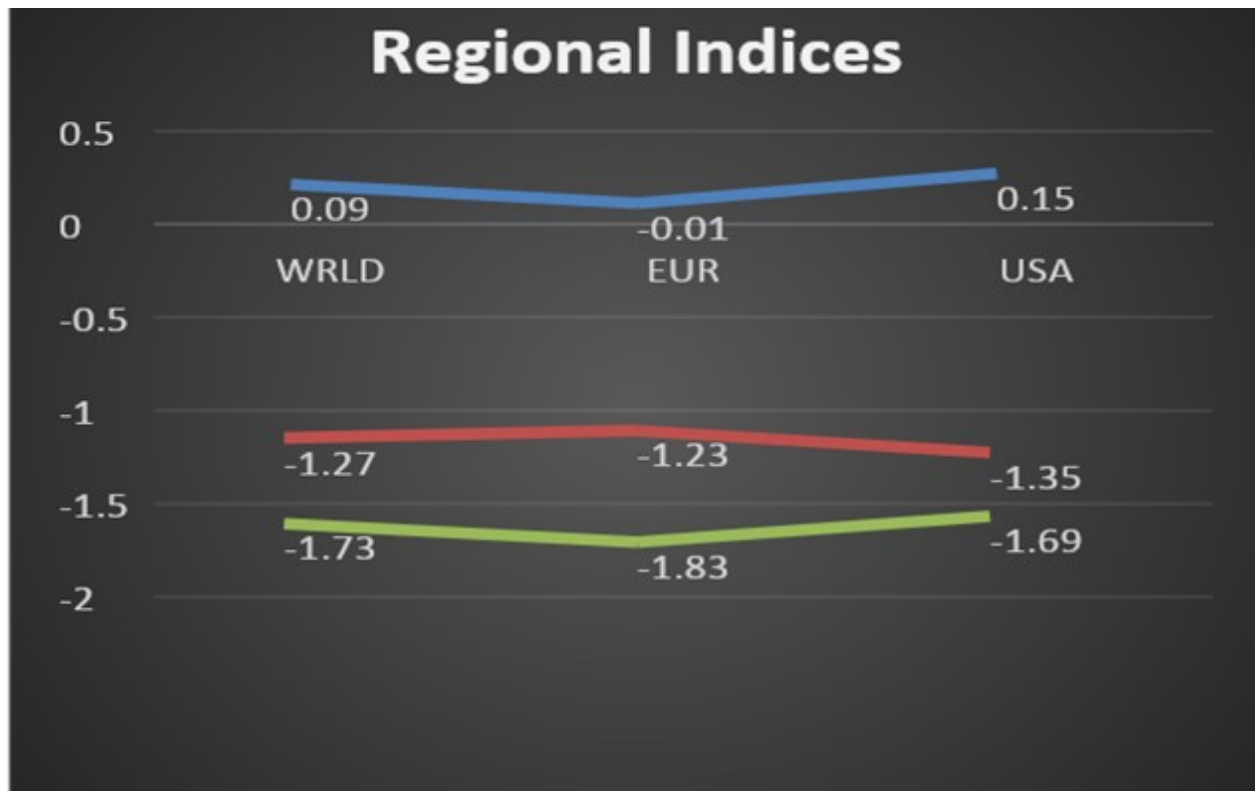

Table 3: Phase 1 Daily Return

The return and volatility had been divided into three phases. Phase- 1 which started in China from 1 Jan 2020 till the second week of February (14 Feb 2020). II Phase started in Europe from after 14 Feb 2020 till 28 February 2020. III Phase started in the USA till date. The data has been analysed graphically to highlight the returns and volatility in the different phases.

\begin{tabular}{|l|l|l|l|}
\hline $\begin{array}{l}\text { Mean } \\
(\%)\end{array}$ & $\begin{array}{l}\text { Standard } \\
\text { Deviation }(\%)\end{array}$ & $\begin{array}{l}\text { Min. } \\
(\%)\end{array}$ & $\begin{array}{l}\text { Max. } \\
(\%)\end{array}$ \\
\hline 0.04 & 0.07 & 0.00 & 0.29 \\
\hline 0.49 & 2.30 & 0.00 & 15.51 \\
\hline 0.06 & 0.11 & 0.00 & 0.57 \\
\hline 0.01 & 0.02 & 0.00 & 0.06 \\
\hline 0.48 & 2.10 & 0.01 & 13.21 \\
\hline 0.29 & 1.33 & 0.01 & 8.87 \\
\hline 0.04 & 0.04 & 0.00 & 0.18 \\
\hline 0.04 & 0.06 & 0.00 & 0.19 \\
\hline 0.03 & 0.04 & 0.00 & 0.16 \\
\hline 0.05 & 0.04 & 0.01 & 0.15 \\
\hline 0.53 & 3.43 & 0.01 & 24.03 \\
\hline 0.04 & 0.05 & 0.00 & 0.21 \\
\hline 0.19 & 0.26 & 0.03 & 1.07 \\
\hline 1.75 & 8.81 & 0.00 & 62.11 \\
\hline 0.02 & 0.01 & 0.01 & 0.04 \\
\hline 0.26 & 0.44 & 0.06 & 2.36 \\
\hline 0.15 & 0.17 & 0.05 & 0.86 \\
\hline
\end{tabular}

Table 3: Volatility

Table 3: Volatility 


\section{E-ISSN: 2582-502X \\ Asiatic Society for}

\begin{tabular}{|l|l|l|l|l|l|l|l|l|}
\hline & $\begin{array}{l}\text { Mean } \\
(\%)\end{array}$ & $\begin{array}{l}\text { Standard } \\
\text { Deviation } \\
(\%)\end{array}$ & $\begin{array}{l}\text { Min. } \\
(\%)\end{array}$ & $\begin{array}{l}\text { Max. } \\
(\%)\end{array}$ & $\begin{array}{l}\text { Mean } \\
(\%)\end{array}$ & $\begin{array}{l}\text { Standard } \\
\text { Deviation } \\
(\%)\end{array}$ & $\begin{array}{l}\text { Min. } \\
(\%)\end{array}$ & $\begin{array}{l}\text { Max } \\
(\%)\end{array}$ \\
\hline WRLD & 0.09 & 0.57 & -1.65 & 1.35 & 0.00 & 0.07 & 0.01 & 0.01 \\
\hline EUR & -0.01 & 0.67 & -2.39 & 1.43 & 0.00 & 0.00 & 0.00 & 0.00 \\
\hline USA & 0.15 & 0.70 & -1.77 & 1.55 & 0.00 & 0.07 & 0.01 & 0.01 \\
\hline ASIA & -0.01 & 0.83 & -1.97 & 1.90 & 0.03 & 1.64 & 0.06 & 0.07 \\
\hline ITL & 0.04 & 0.93 & -2.34 & 2.41 & 0.00 & 0.07 & 0.01 & 0.01 \\
\hline SPN & 0.04 & 0.75 & -2.10 & 1.51 & 0.01 & 0.29 & 0.01 & 0.02 \\
\hline CHN & 0.05 & 1.30 & -2.91 & 2.81 & 0.00 & 0.00 & 0.00 & 0.00 \\
\hline GER & -0.01 & 0.84 & -2.71 & 1.40 & 0.03 & 1.64 & 0.06 & 0.07 \\
\hline FRA & -0.04 & 0.72 & -2.63 & 1.39 & 0.00 & 0.07 & 0.01 & 0.01 \\
\hline KOR & 0.06 & 1.61 & -3.87 & 3.83 & 0.01 & 0.29 & 0.01 & 0.02 \\
\hline SWZ & 0.10 & 0.54 & -1.46 & 1.31 & 0.00 & 0.00 & 0.00 & 0.00 \\
\hline UK & -0.11 & 0.69 & -2.41 & 1.57 & 0.03 & 1.64 & 0.06 & 0.07 \\
\hline BC & 1.12 & 2.82 & -3.54 & 6.96 & 0.00 & 0.07 & 0.01 & 0.01 \\
\hline WTI & -0.48 & 1.68 & -5.05 & 3.01 & 0.00 & 0.00 & 0.00 & 0.00 \\
\hline SLD & 0.12 & 0.60 & -1.34 & 1.33 & 0.03 & 1.64 & 0.06 & 0.07 \\
\hline & 0.06 & 0.27 & -0.57 & 0.57 & 0.00 & 0.07 & 0.01 & 0.01 \\
\hline
\end{tabular}

Phase 1: Daily return and Volatility

Phase 2: Returns and Volatility

\begin{tabular}{|l|l|l|l|l|}
\hline & $\begin{array}{l}\text { Mea } \\
\mathrm{n} \\
(\%)\end{array}$ & $\begin{array}{l}\text { Standard } \\
\text { Deviatio } \\
\mathrm{n}(\%)\end{array}$ & $\begin{array}{l}\text { Min } \\
(\%)\end{array}$ & $\begin{array}{l}\text { Max } \\
(\%)\end{array}$ \\
\hline $\begin{array}{l}\text { WRL } \\
\mathrm{D}\end{array}$ & -1.27 & 1.40 & - & 0.40 \\
\hline EUR & -1.23 & 1.61 & $\begin{array}{l}- \\
3.79\end{array}$ & 0.55 \\
\hline USA & -1.35 & 1.70 & - & 0.49 \\
\hline ASIA & -0.86 & 0.60 & - & 0.13 \\
\hline ITL & -1.08 & 2.12 & - & 1.44 \\
\hline SPN & -1.17 & 1.73 & - & 0.93 \\
\hline CHN & -0.56 & 1.06 & - & 0.79 \\
\hline GER & -1.27 & 1.55 & - & 0.72 \\
\hline FRA & -1.16 & 1.55 & - & 0.54 \\
\hline KOR & -1.51 & 1.94 & - & 2.05 \\
\hline SWZ & -1.07 & 1.59 & - & 0.86 \\
\hline UK & -1.36 & 1.77 & - & 0.32 \\
\hline BC & -1.76 & 3.87 & - & 5.24 \\
\hline WTI & -1.00 & 2.23 & - & 2.35 \\
\hline GLD & 0.03 & 1.65 & - & 1.90 \\
\hline & & & 3.78 & \\
\hline & & & \\
\hline & & & \\
\hline
\end{tabular}

\begin{tabular}{|l|l|l|l|}
\hline $\begin{array}{l}\text { Mean } \\
(\%)\end{array}$ & $\begin{array}{l}\text { Standard } \\
\text { Deviation } \\
(\%)\end{array}$ & $\begin{array}{l}\text { Min. } \\
(\%)\end{array}$ & $\begin{array}{l}\text { Max. } \\
(\%)\end{array}$ \\
\hline 0.04 & 1.66 & 0.02 & 0.10 \\
\hline 0.00 & 0.01 & 0.00 & 0.00 \\
\hline 0.04 & 1.66 & 0.02 & 0.10 \\
\hline 0.16 & 15.51 & 0.09 & 0.34 \\
\hline 0.04 & 1.66 & 0.02 & 0.10 \\
\hline 0.05 & 4.87 & 0.03 & 0.13 \\
\hline 0.00 & 0.01 & 0.00 & 0.00 \\
\hline 0.16 & 15.51 & 0.09 & 0.34 \\
\hline 0.04 & 1.66 & 0.02 & 0.10 \\
\hline 0.05 & 4.87 & 0.03 & 0.13 \\
\hline 0.00 & 0.01 & 0.00 & 0.00 \\
\hline 0.16 & 15.51 & 0.09 & 0.34 \\
\hline 0.04 & 1.66 & 0.02 & 0.10 \\
\hline 0.00 & 0.01 & 0.00 & 0.00 \\
\hline 0.16 & 15.51 & 0.09 & 0.34 \\
\hline 0.04 & 1.66 & 0.02 & 0.10 \\
\hline 0.05 & 4.87 & 0.03 & 0.13 \\
\hline
\end{tabular}

Phase 2: Returns and Volatility 
E-ISSN: 2582-502X Astatic ociety for ocial trience ßResearch, Vol 3 (1)

Phase 3: Returns and Volatility

\begin{tabular}{|l|l|l|l|l|}
\hline & $\begin{array}{l}\text { Mean } \\
(\%)\end{array}$ & $\begin{array}{l}\text { Standard } \\
\text { Deviation } \\
(\%)\end{array}$ & $\begin{array}{l}\text { Min. } \\
(\%)\end{array}$ & $\begin{array}{l}\text { Max. } \\
(\%)\end{array}$ \\
\hline WRLD & -1.73 & 5.05 & -10.44 & 5.75 \\
\hline EUR & -1.83 & 4.39 & -14.06 & 1.81 \\
\hline USA & -1.69 & 6.29 & -12.92 & 8.71 \\
\hline ASIA & -1.29 & 2.34 & -5.19 & 2.75 \\
\hline ITL & -2.35 & 6.37 & -20.54 & 6.60 \\
\hline SPN & -2.17 & 5.60 & -17.22 & 5.32 \\
\hline CHN & -0.84 & 2.97 & -6.09 & 3.79 \\
\hline GER & -2.11 & 4.73 & -15.09 & 3.69 \\
\hline FRA & -1.99 & 5.07 & -14.90 & 5.12 \\
\hline KOR & -1.67 & 4.97 & -11.00 & 10.05 \\
\hline SWZ & -0.97 & 3.62 & -11.33 & 3.91 \\
\hline UK & -2.13 & 4.41 & -14.21 & 1.49 \\
\hline BC & -2.49 & 11.02 & -31.57 & 15.83 \\
\hline WTI & -3.98 & 14.10 & -38.83 & 21.36 \\
\hline GLD & -0.43 & 2.04 & -4.88 & 2.59 \\
\hline Trsry & 0.10 & 1.32 & -2.10 & 1.82 \\
\hline S\&P & -0.93 & 1.31 & -3.42 & 0.73 \\
\hline & & & &
\end{tabular}

\begin{tabular}{|l|l|l|l|}
\hline $\begin{array}{l}\text { Mean } \\
(\%)\end{array}$ & $\begin{array}{l}\text { Standard } \\
\text { Deviation } \\
(\%)\end{array}$ & $\begin{array}{l}\text { Min. } \\
(\%)\end{array}$ & $\begin{array}{l}\text { Max. } \\
(\%)\end{array}$ \\
\hline 0.23 & 147.81 & 0.03 & 0.30 \\
\hline 0.08 & 0.00 & 0.00 & 0.02 \\
\hline 0.23 & 147.81 & 0.03 & 0.30 \\
\hline 0.48 & 2203.55 & 0.12 & 0.93 \\
\hline 0.23 & 147.81 & 0.03 & 0.30 \\
\hline 0.10 & 568.71 & 0.03 & 0.25 \\
\hline 0.08 & 0.00 & 0.00 & 0.02 \\
\hline 0.48 & 2203.55 & 0.12 & 0.93 \\
\hline 0.23 & 147.81 & 0.03 & 0.30 \\
\hline 0.10 & 568.71 & 0.03 & 0.25 \\
\hline 0.08 & 0.00 & 0.00 & 0.02 \\
\hline 0.48 & 2203.55 & 0.12 & 0.93 \\
\hline 0.23 & 147.81 & 0.03 & 0.30 \\
\hline 0.08 & 0.00 & 0.00 & 0.02 \\
\hline 0.48 & 2203.55 & 0.12 & 0.93 \\
\hline 0.23 & 147.81 & 0.03 & 0.30 \\
\hline 0.10 & 568.71 & 0.03 & 0.25 \\
\hline & & & \\
\hline & & & \\
\hline 0.03 & & & \\
\hline & & & \\
\hline
\end{tabular}

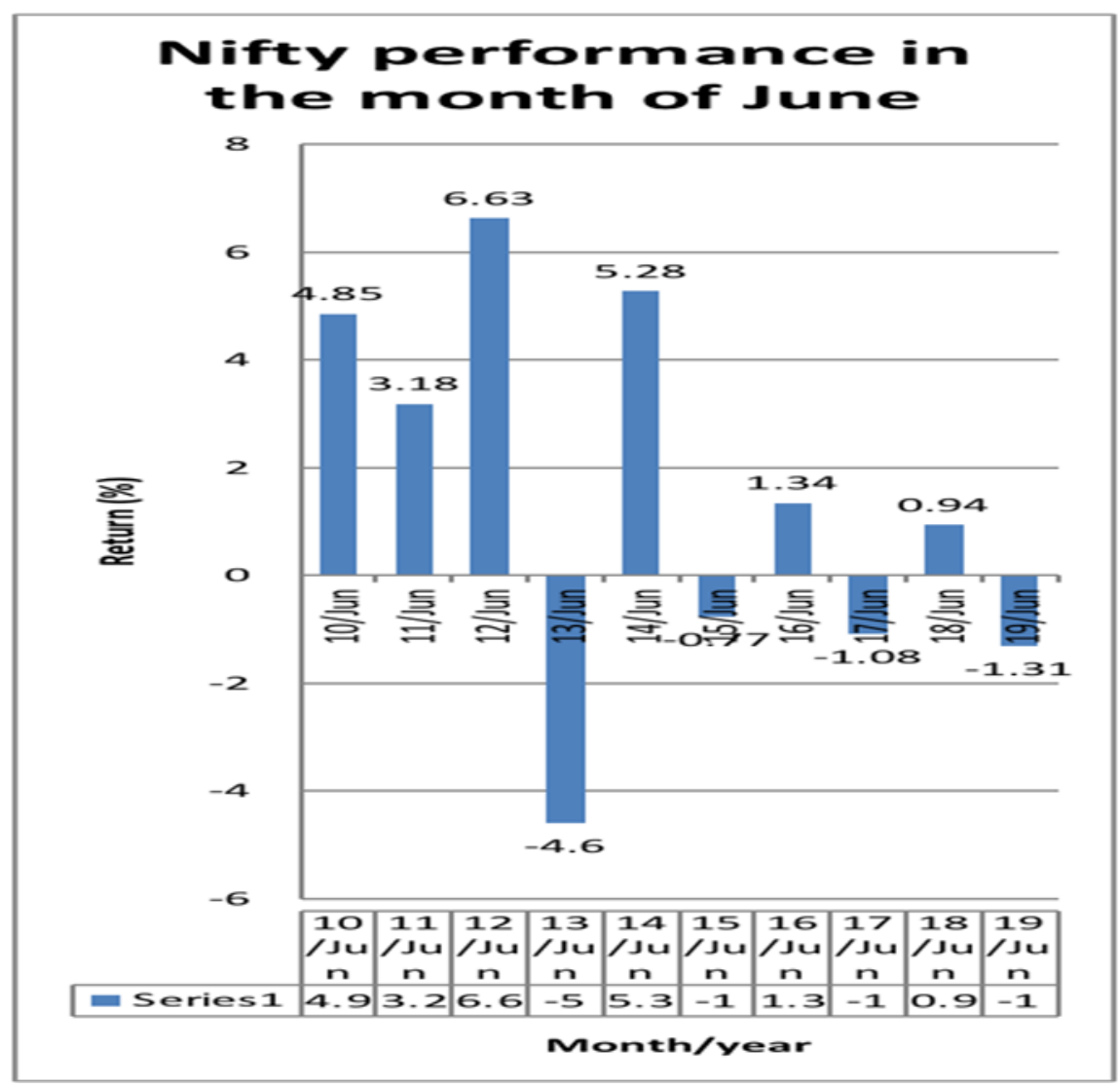




\section{E-ISSN: 2582-502X Asíatic Society for}

\section{Changes in Nifty during last month June due to the covid 19}

The month of trend in the market. The opening of the lockdown raises hope in the stock market. Although the markets were not in a profitable situation from the last week of May, but it gradually started improving in the month of June. June had shown the bull The uprising of the COVID-19 pandemic was called to be a curse for the stock markets growth and indeed it struck them a hard way but going through the situation it was observed that the global players from the developed countries have had happened to sustain themselves and have gone on the rally of upward growth, although some experts from the experience have called it predictable adaptability of the markets. Apart from the developments made by the markets of the developed countries, the Indian Stock market despite of facing the economic and pandemic crisis in the country has surprisingly done well and has also attracted billions of foreign investments making India the only developing country to do this well in such times.

By the end of the month of May the market has been observed to start showing up the signs of gains from the pandemic downfall making it a possibility to make more gains in the month of June which may include few downs too. With past lockdowns imposed and the future unlocks proposed, a significant situation of the economy to breathe again is expected. The record of past 10 year has shown a majority of the bull market over the bear market making it probable to assume that the chances of the market to do well are high however there are other factors which are there to be found supporting such predictions, from USChinese trade dispute to Indo-China standoff and the reports of foreign firms looking out for a transfer to India as a new operation base has affected the market in a way or another. With the continue rise in the cases it is to be seen that the market has now also continued itself to adapt with the situation and operate accordingly.

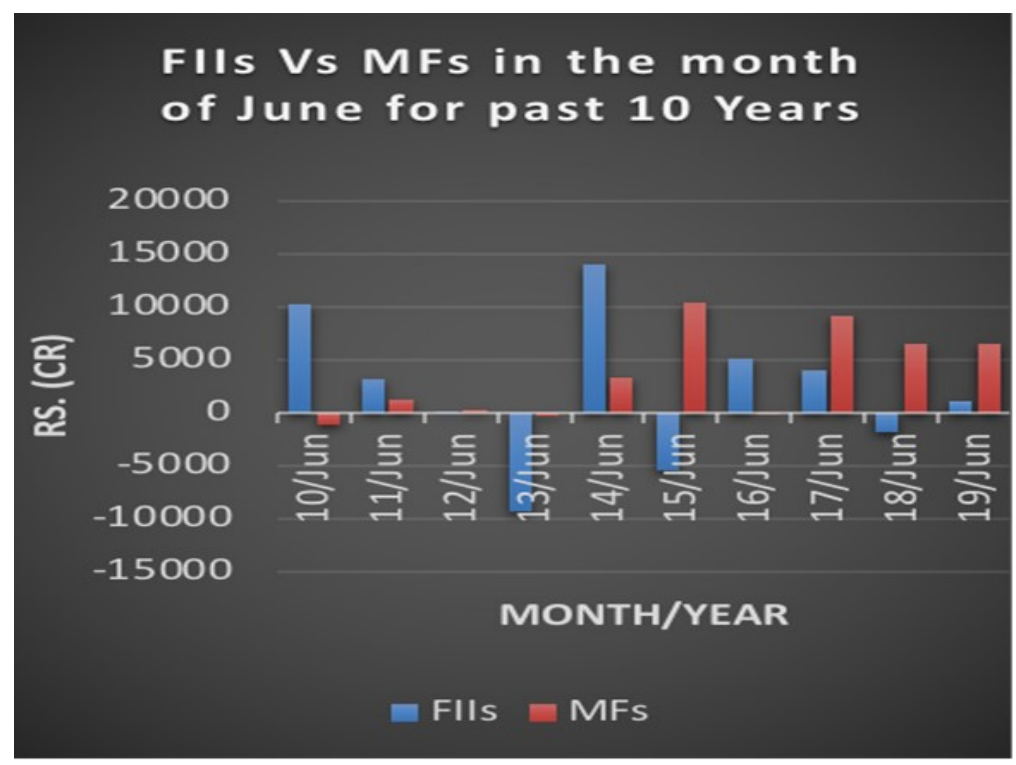




\section{E-ISSN: 2582-502X

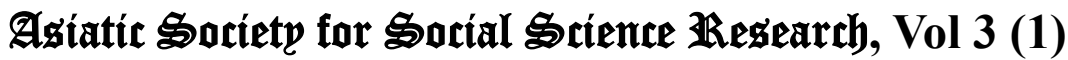

\section{Conclusion}

Coronavirus/ COVID-19 have emerged as a pandemic for the whole world which has made the whole world go through this serious health crisis and a stand still position. Like other countries India by the time this research is being done has incurred more than 6lakh confirmed cases of it. Apart from these back foot points the country has also seen a drop of economic activities, but the performance of Indian Stock Market has managed to keep up hopes for future times to come and has also made people rely on it for some serious earnings in this period. Though the future is uncertain the stock market is the only place which has the promising returns to give.

\section{REFERENCES}

Ali, Mohsin, Nafis Alam, and Syed Aun R. Rizvi. 2020. "Coronavirus (COVID-19) - an Epidemic or Pandemic for Financial Markets.” Journal of Behavioral and Experimental Finance 27 (May): 100341. doi:10.1016/j.jbef.2020.100341.

Conlon, Thomas, and Richard McGee. 2020. "Safe Haven or Risky Hazard? Bitcoin during the Covid-19 Bear Market.” Finance Research Letters 35 (May): 101607. doi:10.1016/j.frl.2020.101607.

Goodell, John W. 2020. “COVID-19 and Finance: Agendas for Future Research.” Finance Research Letters 35 (April): 101512. doi:10.1016/j.frl.2020.101512.

Liu, HaiYue, Aqsa Manzoor, CangYu Wang, Lei Zhang, and Zaira Manzoor. 2020. “The COVID-19 Outbreak and Affected Countries Stock Markets Response.” International Journal of Environmental Research and Public Health 17 (8): 2800. doi:10.3390/ijerph17082800.

Masoud, Najeb M. H. 2013. “The Impact of Stock Market Performance upon Economic Growth.” International Journal of Economics and Financial Issues 3 (4): 788-98. https://www.econjournals.com/index.php/ ijefi/article/view/557.

Mukherjee, Debjiban. 2007. "Comparative Analysis of Indian Stock Market with International Markets." https://www.greatlakes.edu.in/pdf/DebijanMukherjee.pdf.

Ozili, Peterson, and Thankom Arun. 2020. “(PDF) Spillover of COVID-19: Impact on the Global Economy." ResearchGate. March. https://www.researchgate.net/publication/340236487_Spillover_of_COVID19_impact_on_the_Global_Economy.

Yadav, Sameer. 2017. "Stock Market Volatility - A Study of Indian Stock Market - Gjra - Global Journal for Research Analysis.” Www.worldwidejournals.com. April. https://www.worldwidejournals.com/globaljournal-for-research-analysis-GJRA/fileview/April_2017_1492169212_150.pdf.

\section{Websites Referred}

https://www.who.int/news-room/detail/27-04-2020-who-timeline---covid-19)

https://www.ktvu.com/news/how-did-coronavirus-get-its-name

https://www.worldometers.info/coronavirus/country/china/

https://economictimes.indiatimes.com/news/economy/indicators/severe-slowdown-when-will-the-indianeconomy-recover-and-how/articleshow/72310684.cms?from $=\mathrm{mdr}$

https://www.outlookindia.com/outlookmoney/equity/covid-19-impact-on-stock-market-4666

https://coronaworld.info/country/India

https://www.moneycontrol.com/sensex/bse/sensex-live 


\section{E-ISSN: 2582-502X Astatic Gociety for Gocial Sience ßResearch, Vol 3 (1)}

https://www.moneycontrol.com/indian-indices/nifty-50-9.html

https://www.tradingview.com/chart/

https:/www.business-standard.com/podcast/markets/market-wrap-jan-30-indices-at-3-week-closing-lowsensex-tanks-285-pts-120013001195_1.html

https://en.wikipedia.org/wiki/COVID-19_pandemic_lockdown_in_India https://theprint.in/economy/govt-rbi-will-take-necessary-steps-to-deal-with-fear-sentiment-aroundcovid-19-says-cea/380735/

https:/www.moneycontrol.com/news/business/markets/lockdown-winners-12-stocks-turned-multibaggerswhen-market-recovered-21-5190931.html

https://m.economictimes.com/markets/stocks/news/global-funds-load-up-on-indian-stocks-as-virus-shelter-inasia/articleshow/74314380.cms

Corresponding Author: Mr. Rishabh Partap Singh (eMail: rishabhprataps@gmail.com) 